\title{
Overlooked cryptic endemism in copepods: Systematics and natural history of the calanoid subgenus Occidodiaptomus Borutzky 1991 (Copepoda, Calanoida, Diaptomidae)
}

\author{
Federico Marrone ${ }^{\mathrm{a}, *}$, Sabrina Lo Brutto ${ }^{\mathrm{a}}$, Anna K. Hundsdoerfer ${ }^{\mathrm{b}}$, Marco Arculeo ${ }^{\mathrm{a}}$ \\ ${ }^{a}$ Dipartimento di Biologia ambientale e Biodiversità, Università di Palermo, via Archirafi 18, I-90123 Palermo, Italy \\ ${ }^{\mathrm{b}}$ Senckenberg Natural History Collections Dresden, Königsbrücker Landstrasse 159, D-01109 Dresden, Germany
}

\section{A R T I C L E I N F O}

\section{Article history:}

Received 30 May 2012

Revised 8 August 2012

Accepted 17 September 2012

Available online $\mathrm{xxxx}$

\section{Keywords:}

Hemidiaptomus

Molecular evolutionary rates

Morphological conservatism

Sibling species

\begin{abstract}
A B S T R A C T
Our comprehension of the phylogeny and diversity of most inland-water crustaceans is currently hampered by their pronounced morphological bradytely, which contributed to the affirmation of the "Cosmopolitanism Paradigm" of freshwater taxa. However, growing evidence of the existence of cryptic diversity and molecular regionalism is available for calanoid copepods, thus stressing the need for careful morphological and molecular studies in order to soundly investigate the systematics, diversity and distribution patterns of the group.

Diaptomid copepods were here chosen as model taxa, and the morphological and molecular diversity of the species belonging to the west-Mediterranean diaptomid subgenus Occidodiaptomus were investigated with the aim of comparing the patterns of morphological and molecular evolution in freshwater copepods. Three species currently lumped under the binomen Hemidiaptomus (Occidodiaptomus) ingens and two highly divergent clades within $H$. (O.) roubaui were distinguished, thus showing an apparent discordance between the molecular distances recorded and Occidodiaptomus morphological homogeneity, and highlighting a noteworthy decoupling between the morphological and molecular diversity in the subgenus.

Current Occidodiaptomus diversity pattern is ascribed to a combined effect of ancient vicariance and recent dispersal events. It is stressed that the lack of sound calibration points for the molecular clock makes it difficult to soundly temporally frame the diversification events of interest in the taxon studied, and thus to asses the role of morphological bradytely and of accelerated molecular evolutionary rates in shaping the current diversity of the group.
\end{abstract}

(c) 2012 Elsevier Inc. All rights reserved.

\section{Introduction}

Until recently, most inland-water microcrustaceans were considered widespread species whose distribution was mostly regulated by ecological factors. The "Cosmopolitanism Paradigm", based on the observation of the scarce morphological differentiation among presumed conspecific populations along wide areas and of the potentially high capacities of microcrustaceans for passive dispersal, was advocated to explain this hypothesised pattern (see references in: Bohonak and Jenkins, 2003). The model assigned a fundamental role to the resting stages, which are apt to be passively transported by wind, vertebrates or flying insects and that could thus maintain the genetic homogeneity of the species through an extensive gene flow across their distribution ranges (e.g. Mayr, 1963; Bilton et al., 2001). Conversely, growing morphological and molecular evidence has shown that a significant part of

\footnotetext{
* Corresponding author. Fax: +3909123860855.

E-mail address: federico.marrone@unipa.it (F. Marrone).
}

the currently considered widely-distributed morphospecies, i.e. those taxa defined on morphology alone, are in fact groups of closely related species with a more restricted distribution (e.g. Reid, 1998; Lee, 2000; Thum and Derry, 2008, and references therein); these last are sometimes "true" sibling species, completely indistinguishable based on morphology alone. However, there are cases in which the presumed cryptic species are morphologically distinguishable if based on morphological characters which were to date overlooked ("pseudo-sibling species" sensu Knowlton, 1993), thus attesting the dearth of morphological characters of taxonomic utility which afflicts some microcrustacean groups.

The idea of the existence of an important realised gene flow among inland water microcrustacean populations has been recently challenged by the "Monopolization Hypothesis" (De Meester et al., 2002) according to which a combination of founder effect, rapid local adaptation, and resilience due to large egg banks acts against the establishment of "newcomers", thus restricting the extent of actual gene flow in spite of the occurrence of possible frequent dispersal events (the "dispersal-gene flow paradox"). 
In order to correctly understand the speciation patterns, diversity and biogeography of inland water microcrustaceans, a thorough morphological and molecular revision of the existing taxa is thus needed. We are here focusing on the copepod taxon Occidodiaptomus Borutzky 1991, a subgenus belonging to the family Diaptomidae, the calanoid family which dominates the lentic inland water bodies of the Palaearctic region, a key-taxon for lacustrine and pond ecosystems. The species of the family are characterised by limited distribution ranges, which are significantly constrained by the legacies of historical biogeographical events (e.g. Leibold et al., 2010). However, genetic studies proved that our comprehension of the real distribution patterns of the diaptomid species is currently hampered by a gross underestimating of the diversity of the group (e.g. Boileau, 1991; Thum and Derry, 2008; Thum and Harrison, 2009; Makino and Tanabe, 2009; Marrone et al., 2010).

In the Mediterranean region, about one hundred diaptomid species belonging to fourteen genera are currently reported (Dussart and Defaye, 2002). Among these, the subgenus Occidodiaptomus (it belongs to the genus Hemidiaptomus sensu Borutzky et al., 1991 ) is endemic to this area and is currently considered to include the species $H$. (O.) roubaui, $H$. (O.) ingens and $H$. (O.) maroccanus (Table 1). The morphology-based taxonomy of the whole Hemidiaptomus genus is controversial, and there is neither agreement on the taxonomical rank to be attributed to the taxon Occidodiaptomus nor on the relationships of the species belonging to it (e.g. Kiefer, 1973; Marrone and Naselli-Flores, 2004; Stepanova, 2005; Marrone et al., 2011).

In the frame of the growing evidence of the overlooked diversity of microcrustaceans, and in the light of the controversial ideas on the composition, rank and distribution of the taxon Occidodiaptomus (e.g. Stepanova, 2005; Marrone et al., 2010), we investigated the taxonomy, distribution and phylogeography of the species of the subgenus Occidodiaptomus with the following aims: (i) testing the monophyly and the taxonomical rank of Occidodiaptomus within the family Diaptomidae, (ii) investigating the phylogenetic relationships among the taxa belonging to the subgenus Occidodiaptomus, and (iii) proposing a hypothesis on the phylogeography of the group. In fact, in order to make sound inferences on the systematics and phylogeny of the members of the subgenus Occidodiaptomus, it is first necessary to check for the monophyly of the taxon itself, and then probe the coupling of morphological and molecular data on the inter-taxa phylogenetic relationships and on the hypothesised natural history of the group.

These aims are pursued here by implementing both molecular analyses and a cladistic analysis of morphological characters. Analyses were performed following a hierarchical taxonomical approach: (i) conservative nuclear ribosomal DNA genes (18S and
28S), which are widely used to resolve relationships at the genusand family-rank in copepods (e.g.: Bucklin et al., 2003; Braga et al., 1999; Wyngaard et al., 2010; Blanco-Bercial et al., 2011), were used to investigate the taxonomical rank to be assigned to the taxon Occidodiaptomus in the frame of the family Diaptomidae, (ii) species grouping based on a matrix of morphological characters was compared to that obtained through molecular analyses, (iii) fragments of the mitochondrial genes 165 and Cyt-b were used to check for the monophyly of Occidodiaptomus and to investigate the relationships among the taxa belonging to it. Finally, the COI gene was chosen as an additional mitochondrial marker for further testing the monophyly of the clades singled out with the other mitochondrial markers in the only $H$. ingens s.l. (see Section 4); the COI is a widely used marker for species identification in the frame of the "barcoding of life" project and it proved to be a suitable marker for species identification in crustaceans (Hebert et al., 2003; Costa et al., 2007, and references therein).

\section{Material and methods}

\subsection{Taxon sampling and identification}

Occidodiaptomus samples were collected throughout the distribution range of the subgenus. Particular attention was paid to collect samples from the terra typica of each species and subspecies described in the group (Table S1). In order to test the taxonomical arrangement proposed by Stepanova (2005), six taxa belonging to the other Hemidiaptomus subgenera (i.e. Hemidiaptomus s.str. Sars and Gigantodiaptomus Kiefer) and nine species belonging to other diaptomid genera were included in the molecular analyses. Calanipeda aquaedulcis Kritchagin 1873, a representative of the family Pseudodiaptomidae, was chosen as outgroup in some of the analyses because this family is closely related to the family Diaptomidae (Bradford-Grieve et al., 2010; Figueroa, 2011). The complete list of studied material and its occurrence localities is reported in Table S1.

Sampling was carried out with $125 \mu \mathrm{m}$ mesh-sized hand- and towing-nets. Specimens were fixed in situ with 80-95\% ethanol, sorted under a stereomicroscope and stored in $95 \%$ ethanol at $4{ }^{\circ} \mathrm{C}$. If available, ten males and ten females from each population were prepared according to Huys and Boxshall (1991) to be identified according to Kiefer (1978), Borutzky et al. (1991), and Einsle (1993).

\subsection{Cladistic analysis of the morphological characters}

Thirty-four morphological characters traditionally considered to be taxonomically informative were selected for analysis; these

\section{Table 1}

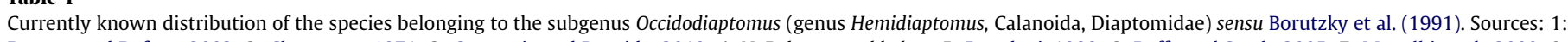

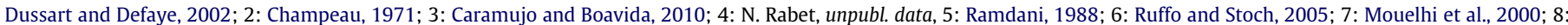

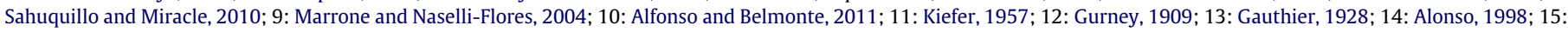
Richard, 1888; 16: Kiefer, 1954; 17: Kiefer, 1973; 18: Marrone et al., 2010.

\begin{tabular}{|c|c|c|c|}
\hline Species & Distribution & Sources & Notes \\
\hline $\begin{array}{l}\text { H. (O.) roubaui } \\
\text { (Richard, 1888) }\end{array}$ & $\begin{array}{l}\text { Portugal, Spain, France, } \\
\text { Sardinia, Morocco? }\end{array}$ & $\begin{array}{l}1,2,3,4,5,6,7,14 \\
11,15,17\end{array}$ & $\begin{array}{l}\text { The species was erroneously reported for Corsica and Peninsular Italy. Its actual presence in } \\
\text { Morocco is in need of confirmation }\end{array}$ \\
\hline & & & $\begin{array}{l}\text { The subspecies } H \text {. roubaui lauteborni was described based on a French population and later } \\
\text { found to be synonymous of the nominal subspecies }\end{array}$ \\
\hline
\end{tabular}

H. (O.) ingens (Gurney, 1909) Spain, Algeria, Tunisia, Corsica, Sicily, Peninsular Italy
$1,2,8,9,10,11,12$, The subspecies $H$. ingens inermis was described for Algeria and later posed in synonymy with $13,17,18$ the nominal subspecies. A recent study (18) supports the existence of independent lineages of species rank within the binomen $H$. ingensits
H. (O.) maroccanus
Southern Spain, Morocco
$1,7,14,16,17$
Its presence in southern France, reported by 1 and 9, is erroneous

(Kiefer, 1954) 
are related to the chaetotaxy and ornamentation of male and female first antennae, the shape of female genital segment and of the male urosome, and the shape and ornamentation of the male fifth pair of swimming legs (Table S2). Twelve Hemidiaptomus taxa (11 species and 2 subspecies) were included in the analysis, and some species belonging to different diaptomid genera were used as outgroups (Table S1). All the taxa were studied on original material with the only exception of Hemidiaptomus brehmi, H. tracicus and $H$. dischensis, for which no samples were available but for which reliable drawings are available in the literature (Kiefer, 1978; Petkovski, 1983).

Both bi- and multi-status characters were used in the cladistic analysis. These were all considered unweighted and unordered as we are currently missing sound information on the ancestral state of all the studied characters but the antennular chaetotaxy (Huys and Boxshall, 1991; Boxshall and Huys, 1998). The morphological matrix was analysed under the Maximum Parsimony (MP) optimality criterion using the software PAUP (Swofford, 2003); a 50\% majority rule consensus tree was produced with the branch-andbound search $($ maxtrees $=100)$.

\subsection{DNA extraction, amplification and sequencing}

Prior to DNA extraction, specimens were carefully cleaned under the stereomicroscope and soaked in double-distilled water for 2-3 h. DNA was then extracted using whole specimens and following the "DNEasy - Animal Tissue Kit" (QIAGEN) protocol or a phenol-chloroform extraction following the procedure described in Korn et al. (2006).

$18 \mathrm{~S}$ and $28 \mathrm{~S}$ nuclear ribosomal genes and three mitochondrial genes (16S, Cyt-b, and COI) were amplified using different primer pairs and thermal cycling conditions (Table S3).

For $18 \mathrm{~S}$ and $28 \mathrm{~S}$, the PCR mix consisted of $17.25 \mu$ double-distilled water, $2.5 \mu \mathrm{l}$ Buffer $10 \times, 1.8 \mu \mathrm{l} \mathrm{MgCl}_{2}$ solution $(25 \mathrm{mM})$, $0.2 \mu \mathrm{ldNTPs}(20 \mathrm{mM}), 0.25 \mu \mathrm{l}$ of each primer $(10 \mu \mathrm{M}), 0.25 \mu \mathrm{l}$ Taq Polymerase $5 \mathrm{u} / \mu \mathrm{l}$, and $1.5 \mu \mathrm{l}$ of DNA template, for a total volume of $25 \mu \mathrm{l}$.

For all mitochondrial fragments, the PCR mix consisted of $17.32 \mu$ l double-distilled water, $2.5 \mu$ l Buffer $10 \times, 2 \mu \mathrm{MgCl}_{2}$ solution $(25 \mathrm{mM}), 0.36 \mu \mathrm{ldNTPs}(10 \mathrm{mM}$ of each), $0.43 \mu \mathrm{l}$ of each primer $(10 \mu \mathrm{M}), 0.28 \mu \mathrm{l} \mathrm{Taq}$ Polymerase $5 \mathrm{u} / \mu \mathrm{l}$ and $0.6 \mu \mathrm{l}$ of DNA template, for a total volume of $25 \mu \mathrm{l}$.

After PCR, $5 \mu$ of each PCR product were separated by electrophoresis on a $2 \%$ agarose gel at $70 \mathrm{~V}$ for $1 \mathrm{~h}$ and visualised with a UV Transilluminator. When PCR products showed a clear and single band of the correct expected length, they were purified using the Exo-SAP-IT kit and sequenced with an ABI 3130xL (Applied Biosystem) sequencer. The forward primers were used for direct sequencing of the PCR product, and the sequences' quality was checked with the Applied Biosystems Sequence Scanner v1.0 software. Only sequences with continuous reads of high quality bases (defined as those bases with a QV score greater than 20) were used. When the sequences were not of sufficient quality, the complement/reverse sequences were obtained additionally. Mega5 (Tamura et al., 2011) was used to translate in amino acids the sequences of protein-coding genes (i.e. Cyt-b and COI) in order to check for the possible presence of frameshifts or premature stop codons, which would indicate the presence of sequencing errors or pseudogenes.

\subsection{Sequence alignment and analyses}

Three datasets were analysed in the frame of this study. A first dataset included the $28 \mathrm{~S}$ and $18 \mathrm{~S}$ sequences of both Hemidiaptomus s.l. and non-Hemidiaptomus taxa, and it was used to test the hypothesis that the currently considered Hemidiaptomus subgenera might in fact deserve the rank of independent genera. A second dataset ("16S and Cyt-b") including 165 and Cyt-b sequences was used to investigate the monophyly of the subgenus Occidodiaptomus, and to test for the possible presence of cryptic species. Finally, a third dataset including COI sequences ("COI") was used to further test the consistency of the different lineages observed within $H$. ingens s.l. by the analyses performed on the " $16 \mathrm{~S}$ and Cyt-b" dataset and by a previous preliminary study (Marrone et al., 2010).

Chromatograms were imported and edited with Chromas Lite 2.01 (Technelysium Pty. Ltd.) and aligned with BioEdit (Hall, 1999). The sequences were deposited in GenBank (Table S4 - it will be realised upon acceptance of the $\mathrm{ms}$ ).

The ILD test (Farris et al., 1995), implemented in PAUP as Partition Homogeneity Test, was performed in order to test whether two or more fragments could be combined in a unique dataset. According to Cunningham (1997), when $P>0.01$ the partitions are not incongruent, and thus it is possible to put them in a single dataset (see also: Barker and Lutzoni, 2002).

Bayesian (BA), Maximum Parsimony (MP), and Maximum Likelihood (ML) analyses were performed as implemented in MrBayes 3.1.2 (Huelsenbeck and Ronquist, 2001), PAUP* 4.0b10 (Swofford, 2003), and PhyMl v.3 (Guindon and Gascuel, 2003), respectively. As a measure of branch support, bootstrap values were calculated with 1000 replicates in the MP and ML trees. Nodes support of BA trees were evaluated by their posterior probabilities. For Maximum Likelihood and Bayesian analyses, the best evolutionary model for each dataset was selected using mrModeltest (Nylander, 2004).

\subsection{Nuclear dataset}

The two nuclear fragments could be combined to be analysed together as the ILD test showed that there was no discordance in their phylogenetic signal (20 OTUs; 1000 reps.; $P=0.239$ ). The combined dataset was thus analysed under MP and ML, and using BA.

The best-fit model for the combined dataset was a Generalised Time-Reversible model plus Invariant sites plus Gamma distributed model $(G T R+I+G)$, selected by AIC; parameter values can be obtained from the first author upon request.

\subsection{Mitochondrial datasets}

The "16S and Cyt-b" dataset includes fragments of Cyt-b and 16S sequences for three outgroup taxa (Diaptomus cyaneus, D. serbicus, and Metadiaptomus chevreuxi) and 53 Hemidiaptomus specimens, belonging to the three Hemidiaptomus subgenera sensu (Borutzky et al., 1991). The ILD test showed that the $16 \mathrm{~S}$ and Cyt-b fragments presented no discordance in the phylogenetic signal (56 OTUs; 1000 reps.; $P=0.236$ ), and that they could then be combined in a single sequence. The best-fit model for the combined dataset was a Generalised Time-Reversible model plus Invariant sites plus Gamma distributed model (GTR + I + G), selected by AIC; parameter values can be obtained from the first author upon request.

The Likelihood Ratio Test was carried out on this dataset in order to check for the possibility of using a molecular clock for the dating of some nodes. This was done by estimating the likelihood for the molecular trees under the best evolutionary model suggested by MrModeltest, both imposing a molecular clock and after having removed this assumption.

The additional mitochondrial fragment of the COI gene was amplified in all the $H$. ingens s.l. specimens available and in two outgroups (i.e. Hemidiaptomus superbus and Metadiaptomus chevreuxi). No other taxa belonging to the subgenus Occidodiaptomus could be included in the analyses as direct sequencing of COI from $H$. (O.) roubaui and $H$. (O.) maroccanus individuals yielded poor sequence with multiple peaks, suggesting the presence of COI pseudogenes as already observed in other diaptomid calanoids by Thum and Harrison (2009). 
The ILD test was used to test whether the COI fragments could be combined with the $H$. ingens Cyt-b and 16S fragments included in the "16S and Cyt-b" dataset. The test revealed significant differences in incongruence length ( $P=0.001 ; 1000$ replicates), thus the COI data set should not be united to that of the Cyt-b and 16S fragments for a combined analysis. However, at the light of the existing criticisms about the ILD test (e.g. Barker and Lutzoni, 2002; Dowton and Austin, 2002; Ramirez, 2006), the COI dataset was analysed both separately and united with the $16 \mathrm{~S}$ and Cyt-B fragments. The best-fit model for the "COI-only" dataset was a HasegawaKishino-Yano plus Invariant sites plus Gamma distributed model $(\mathrm{HKY}+\mathrm{I}+\mathrm{G})$, while the best-fit model for the "16S, Cyt-B and COI" dataset was a Generalised Time-Reversible plus Invariant sites plus Gamma distributed model $(G T R+I+G)$ (parameter values can be obtained from the first author upon request).

All the mitochondrial datasets were analysed under MP and ML, and using BA.

\subsection{Singling out the cryptic species}

Following De Queiroz's “unified species concept” (De Queiroz, 2007), we consider the "lineages evolving separately from others" as species. The "4x rule" (Birky et al., 2010) was applied to molecular mitochondrial distance matrices within and among the detected allegedly intraspecific clades, this was done based both on uncorrected $p$-distance and ml-distance calculated with PAUP $4.0 \mathrm{~b} 10$ (Swofford, 2003) in order to check if the observed intraspecific clades could be considered separate evolving lineages, i.e. independent species sensu De Queiroz (2007), or if the inter-clades distances were just ascribable to random drifts or other transient effects. The implementation of the $4 \mathrm{x}$ rule on sexual organisms is based on the assumption that the studied mitochondrial genes mirror the behaviour of the nuclear genome. However, it considers that mitochondrial genes of two allopatric lineages will become reciprocally monophyletic earlier than nuclear ones, thus providing the earliest evidence of the occurrence of an allopatric speciation event (Marrone et al., 2010; Baird et al., 2011; Kieneke et al., 2012).

In the frame of this study, the $4 \mathrm{x}$ rule was applied to the Occidodiaptomus taxa which showed a stronger structuring in the phylogenetic reconstructions, i.e. $H$. (O.) ingens s.l. and $H$. (O.) roubaui.

\section{Results}

\subsection{Cladistic analysis of the morphological characters}

Out of 34 unordered and unweighted morphological characters, 28 were parsimony-informative. No cases of intra-taxon morphological variability were observed in the studied taxa, as in the frame of the morphological analysis we considered the two different "forms" of Hemidiaptomus ingens s.l. as different subspecies, i.e. $H$. ingens ingens and $H$. ingens inermis, which are morphologically constant at the intra-population level (Table 2) (see also: Marrone and Naselli-Flores, 2004; Marrone et al., 2010). Conversely, and in accordance with the current taxonomical arrangement, neither $H$. roubaui or $H$. maroccanus exhibited any intraspecific morphological variation.

The $50 \%$ majority rule consensus tree based on 73 equally parsimonious trees (74 steps; CI: 0.5676; HI: 0.4324; RI: 0.7091) showed a topology (Fig. 1), which is in general good accordance with the taxonomical schemes proposed by Kiefer (1978) and Borutzky et al. (1991). The taxa currently ascribed to the genus Hemidiaptomus s.l. form a monophyletic group, where Occidodiaptomus is the best resolved taxon. The species belonging to the other subgenera sensu (Borutzky et al., 1991) constitute, in fact, two coherent groups with the exception of $H$. $(G)$ superbus: this last species, currently considered to belong to the subgenus Gigantodiaptomus (but see Marrone et al., 2011), clusters together with a group including the Hemidiaptomus species currently ascribed to the subgenus Hemidiaptomus S.s. Conversely, the close relationship of $H$. (G.) amblyodon and $H$. (G.) hungaricus is confirmed.

Within the subgenus Occidodiaptomus, $H$. maroccanus is the most divergent species, while $H$. ingens s.l. and $H$. roubaui are more closely related.

\subsection{Nuclear markers}

The tree topologies based on BA (Prset statefreqpr $=$ dirichelet $(1,1,1,1)$; Lset nst $=6$ rates $=9)$, ML (evol mod.: GTR $+\mathrm{I}+\mathrm{G})$, and $\mathrm{MP}$ (Tree length $=302 ; \mathrm{CI}=0.8113 ; \mathrm{HI}=0.1887 ; \mathrm{RI}=0.8100$ ) of a $2206 \mathrm{bp}$ long concatenated fragment of the nuclear ribosomal genes $18 \mathrm{~S}$ and $28 \mathrm{~S}$ are congruent. The consensus tree, rooted on the pseudodiaptomid calanoid copepod Calanipeda aquaedulcis, is reported in Fig. 2. The trees grouped together taxa which are ascribed to currently recognised genera. Conversely, they failed to recover the monophyly of the different Hemidiaptomus subgenera sensu Borutzky et al. (1991). On the other hand, the clear structuring of the two Diaptomus s.l. subgenera (i.e. Diaptomus s.s. vs. Chaetodiaptomus), and the close proximity of Copidodiaptomus and Eudiaptomus, two closely allied genera (Kiefer, 1968), are in good accordance with the current taxonomical arrangement.

\subsection{Mitochondrial markers}

The topologies of the trees based on the "16S and Cyt-b" dataset obtained with the various analyses (BA, ML, MP, see Fig. 3 legend for details) were largely congruent, and described a clear characterisation of the three currently recognised subgenera as described by Borutzky et al. (1991), the only exception being $H$. (G.) superbus (Fig. 3). This last species did not group with any other Hemidiaptomus s.l. species in ML and BA trees (Fig. 3A), and clustered with Hemidiaptomus s.s. instead of with the other Gigantodiaptomus species according to the MP tree (Fig. 3B). Moreover, while the ML and BA trees (Fig. 3A) failed to indicate the relationships between these three "higher rank clades" and represented them with an unresolved polytomy, the MP tree (Fig. 3B) showed a monophyletic Occidodiaptomus clade and a monophylum of Gigantodiaptomus + Hemidiaptomus s.s. Within the species belonging to the subgenus Occidodiaptomus, Hemidiaptomus (O.) maroccanus was identified as the sister species of " $H$. roubaui $+H$. ingens" in both the reconstructions; this species presented low mitochondrial divergences among Spanish and Moroccan populations. Conversely, both Hemidiaptomus roubaui and $H$. ingens showed a remarkable mitochondrial polymorphism. It is possible to single out some clusters within each of these alleged species: H. roubaui showed quite a clear differentiation between its northernmost ("Northern clade", from Northern Spain, France and Sardinia) and southernmost ("Southern clade", from southern Spain and Portugal) populations (cf. Table S1 for the code and collection locality of each specimen). Conversely, the clustering of $H$. ingens specimens did not mirror a clear geographical pattern. The three main clades singled out within $H$. ingens s.l. were hereby named $H$. ingens "1", H. ingens "2", and H. ingens "3" (cf. Fig. 3).

The "COI-only" and "16S, Cyt-b and COI" trees of H. ingens alone presented the same topology at the major nodes, and corroborated that three main clades are present within Hemidiaptomus ingens s.l., although some differences in the branching pattern within each clade among the BA, ML and MP reconstructions are present (Fig. 4). These clades are well supported and in perfect accordance with those evidenced in the "16S and Cyt-b" dataset although some minor differences in the relationships among the populations 
Table 2

Occurrence sites for the morphological subspecies and mitochondrial lineages scored within $H$. (O.) ingens. The coordinates of the sites are reported in Table S1.

\begin{tabular}{|c|c|c|c|}
\hline Site & Location & Morphological subspecies ${ }^{a}$ & Mt-lineage ${ }^{\mathrm{b}}$ \\
\hline Margio di Gallitello & Sicily (Italy) & H. ingens ingens & H. ingens " 1 " \\
\hline Gorgo di Baglio Cofano & Sicily (Italy) & H. ingens ingens & H. ingens "1" \\
\hline Garaet Sejenane & Gouvernorat de Bizerte (Tunisia) & H. ingens ingens & H. ingens „1“ \\
\hline Garaet El Khala & Gouvernorat de Nabeul (Tunisia) & H. ingens ingens & H. ingens " 1 " \\
\hline Garaet Raoued & Gouvernorat de Ariana (Tunisia) & H. ingens ingens & H. ingens "1" \\
\hline Patula Mancina & Apulia (Italy) & H. ingens inermis & H. ingens " 2 " \\
\hline Masseria Paludi & Apulia (Italy) & H. ingens inermis & H. ingens " 2 " \\
\hline Contrada Silva & Apulia (Italy) & H. ingens inermis & H. ingens " 2 " \\
\hline Tre Padule de Suartone & Corsica (France) & H. ingens inermis & H. ingens "2" \\
\hline Santa Manza & Corsica (France) & H. ingens inermis & H. ingens " 2 " \\
\hline Bassa del Cavall & Comunitat Valenciana (Spain) & H. ingens inermis & H. ingens " 2 " \\
\hline Lavajo de Abajo & Comunitat Valenciana (Spain) & H. ingens inermis & H. ingens " 3 " \\
\hline
\end{tabular}

a Sensu Kiefer (1973).

b See text, and Figs. 4 and 5.

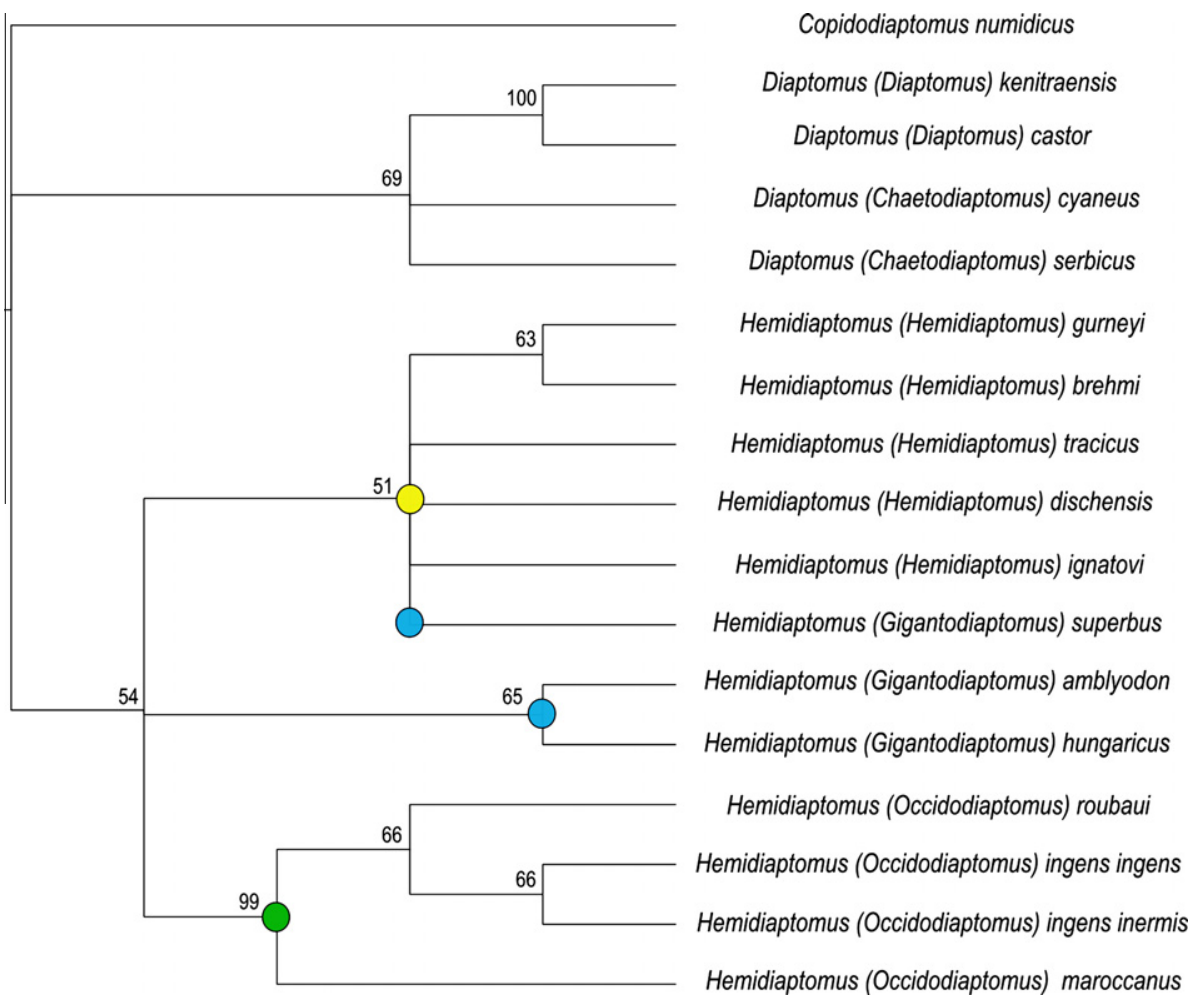

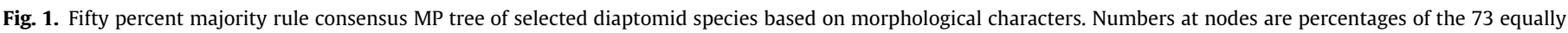

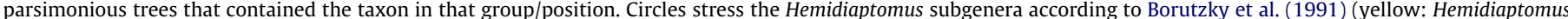

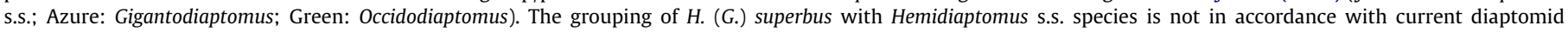
systematics. (For interpretation of the references to colour in this figure legend, the reader is referred to the web version of this article.)

belonging to each single clade were found in the different analyses (data available on request).

\subsection{Molecular clock and timing}

The likelihood ratio test (LRT) was used to test the null hypothesis that the "16S and Cyt-b" dataset evolved under a molecular clock. Using 56 individuals, the difference in log-likelihoods between tree reconstruction with and without a clock enforced was $49(-6525.97650+6575.39114)$. The double of this value is more than the $\chi^{2}$ value of 72.1532 (df: 54 , alfa $=0.05 ; \mathrm{p}<0.0002$ ) indicating that the likelihood values for the reconstructions were significantly different. Clock-like divergence was thus rejected. Furthermore, no fossil records, and thus possible calibration points for the molecular clock, are available for diaptomid copepods.
However, in order to infer at least a rough estimate of the temporal frame in which the splitting of the main evolutionary lineages within the genus Hemidiaptomus s.l. may have occurred (cf. Gomez et al., 2002) two standard evolutionary rates for crustacean mitochondrial DNA (2.6\% $\mathrm{my}^{-1}$, the fastest, and $0.9 \% \mathrm{my}^{-1}$, the slowest one: Dooh et al., 2006; Thum and Harrison, 2009; Milligan et al., 2011 and references therein) were applied to distances between the sequences of the studied species, as shown in Table 3.

\subsection{Singling out the cryptic species}

The $4 \mathrm{x}$ rule was applied to the two mitochondrial datasets separately. In the light of the high level of inter-clades differences observed within Hemidiaptomus ingens s.l., and in accordance with the guidelines of the $4 \mathrm{x}$ rule (Birky et al., 2010), the distance 


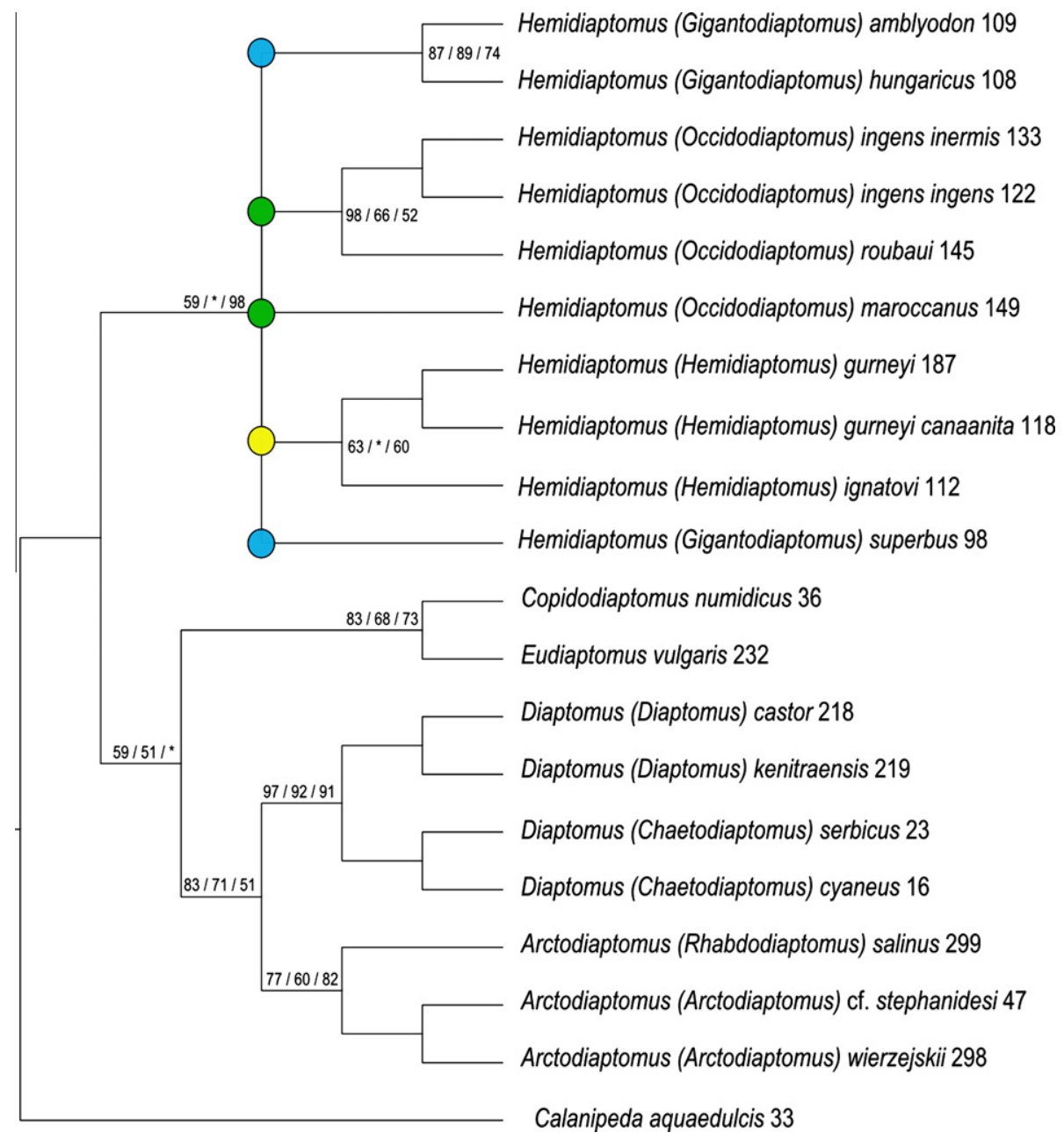

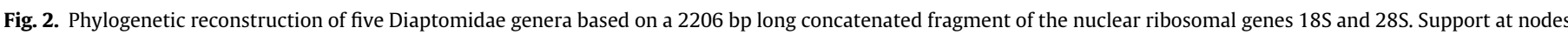

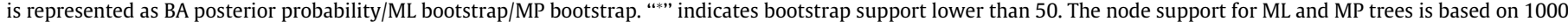

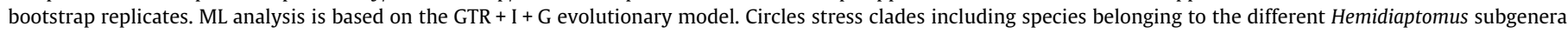

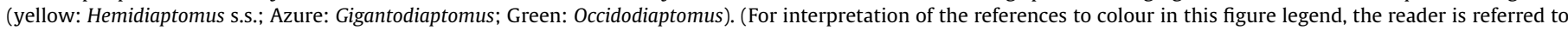
the web version of this article.)

corrected for multiple hits (ml-dist) was used when calculating the inter-clades average distances.

The results of the three analyses carried out on $H$. ingens s.l. were concordant in showing that the inter-clades distances $(K)$ were much higher than $4 \Theta$, based on both the mitochondrial datasets (Table 4). The three $H$. ingens s.l. clades evidenced by the mitochondrial markers (Figs. 3 and 4) thus meet the assumptions of the $4 \mathrm{x}$ rule and are to be considered independently evolving lineages, i.e. species sensu De Queiroz (2007). Conversely, the 4x rule applied to $H$. roubaui (" $16 \mathrm{~S}$ and Cyt-b" dataset only), showed $K$ values much lower than $4 \Theta$, thus not supporting the existence of independently evolving lineages within this taxon (data available from the authors on request).

\section{Discussion}

\subsection{Systematics}

The use of conservative nuclear markers such as $18 \mathrm{~S}$ and $28 \mathrm{~S}$ is widely applied when investigating the monophyly and reciprocal relationships of higher taxa in copepods, while it is known to have loose resolution for the discrimination of infra-generic taxa (Braga et al., 1999; Thum, 2004; Blanco-Bercial et al., 2011; Figueroa,
2011). In the frame of this study, the tree topologies based on the nuclear ribosomal DNA fragments support the monophyly of the genus Hemidiaptomus (Fig. 2), while its subgenera are not clearly resolved, thus supporting the hypothesis that they should not be considered as independent genera, but at most an infrageneric taxonomical rank has to be assigned to the taxa Hemidiaptomus s.s., Gigantodiaptomus and Occidodiaptomus.

Furthermore, the morphological and mitochondrial phylogenetic trees (Figs. 1 and 3) are in good accordance with grouping the Hemidiaptomus s.l. species in three clades; these mirror the taxonomical arrangement of the genus proposed by Borutzky et al. (1991), with clearly-defined monophyletic "Occidodiaptomus", "Hemidiaptomus s.s." and "Gigantodiaptomus" taxa of subgeneric rank. The only outlier is Hemidiaptomus (Gigantodiaptomus) superbus, which clustered with the Hemidiaptomus s.s. species (Figs. 1 and $3 \mathrm{~B}$ ) or did not group with any of the known subgenera (Fig. 3A). This was partly expected, and some doubt on the affinities of this extremely rare Hemidiaptomus species were already raised (Einsle, 1993; Marrone et al., 2011). Our results are thus not in accordance with the re-arrangement of the genus Hemidiaptomus proposed by Stepanova (2005), which assigned to Occidodiaptomus the rank of an independent genus including two subgenera (i.e. Occidodiaptomus s.s. and Balcanodiaptomus); furthermore, the species belonging to the subgenus Balcanodiaptomus 

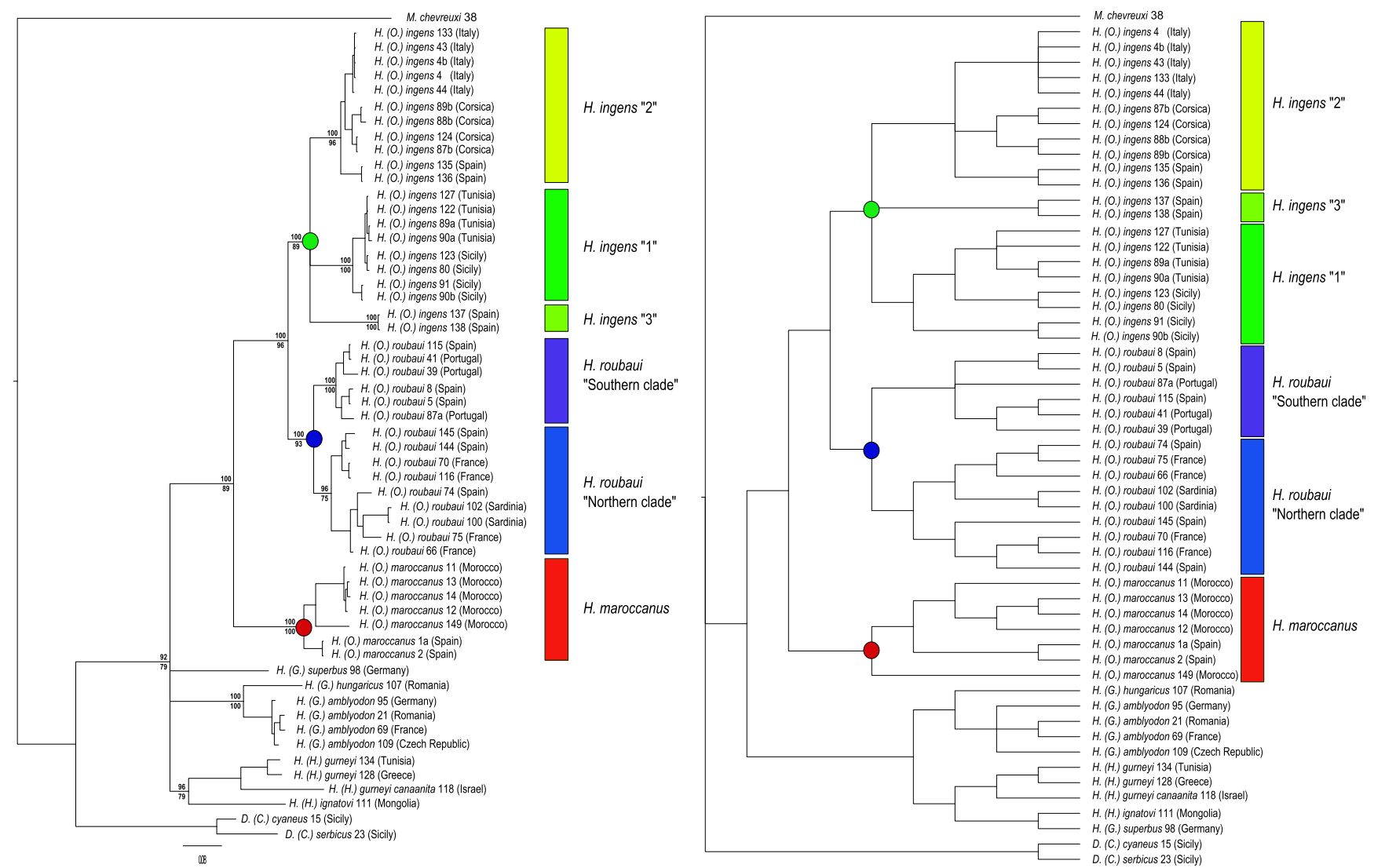

Fig. 3. Phylogenetic reconstructions of Hemidiaptomus species based on the " $16 \mathrm{~S}$ and Cyt-b" dataset. Bayesian tree (Prset statefreqpr $=$ dirichlet $(1,1,1,1)$; Lset nst $=6$ rates $=$ invgamma) $(A)$, node support is shown as posterior probability (upper value) and ML bootstrap value based on 1000 replicates (lower value). Strict consensus MP tree (B) based on 52 equally parsimonious trees (Tree length $=1316 ; \mathrm{CI}=0.4240 ; \mathrm{HI}=0.5760 ; \mathrm{RI}=0.7879$ ). Circles in colour stress the MRCA of the each alleged species within the Occidodiaptomus subgenus (Green: H. (O.) ingens; Blue: H. (O.) roubaui; Red: $H .(O$.) maroccanus). Rectangles in colour stress the molecular clades within each alleged species. (For interpretation of the references to colour in this figure legend, the reader is referred to the web version of this article.)

proposed by Stepanova (2005) constituted a paraphyletic group both based on morphology and on molecular markers and should thus be rejected.

The monophyly of the subgenus Occidodiaptomus is supported by both the morphological and mitochondrial data and six major clades can be singled out within it based on the mitochondrial trees (Fig. 3). The first includes Hemidiaptomus (Occidodiaptomus) maroccanus specimens from Morocco and southern Spain; this species is characterised by morphological and molecular consistency throughout its distribution range.

Hemidiaptomus roubaui specimens are grouped in two major geographically-segregated but morphologically-indistinguishable clades, a "Southern clade" including the populations from southwestern Spain and Portugal, and a "Northern clade" including the north-easternmost populations (northern Spain, France, and Sardinia) (Fig. 3). The output of the $4 x$ rule based on the "16S and Cyt-b" dataset did not support the independent species rank for the two clades of Hemidiaptomus roubaui, which has then to be considered a single, molecularly highly-structured species. However, further studies on ecological or reproductive isolation might provide further insights on the relationships among these two different clades.

Three clades with unresolved relationships can be singled out within Hemidiaptomus (Occidodiaptomus) ingens s.l. based on the "16S and Cyt-b" dataset (Fig. 3). Two of these (i.e. "H. ingens 1" and " $H$. ingens 2") were anticipated by Marrone et al. (2010) based on Cyt-b sequences only, the third one ("H. ingens 3") includes a single population from north-eastern Spain which was not included in the previous work. Although the ILD test showed that the COI sequences ("COI dataset") could not be combined with the $16 \mathrm{~S}$ and Cyt-b sequences in a single dataset, the tree topologies based on the COI only (Fig. 4) are in accordance with the "16S and Cyt-b" and the "16S, Cyt-b and COI" datasets in singling out the three clades within $H$. ingens s.l.

Out of the three clades, "H. ingens 1 ", occurring in Tunisia and Sicily, can be readily identified based on the morphology of the male specimens: it is the only Hemidiaptomus species whose males bear 1-3 strong setae at the distal part of the endopodite of the left $\mathrm{P} 5$; conversely, the clades " $H$. ingens 2 ", occurring in Spain, Corsica and southern Italy, and "H. ingens 3", occurring in a single Spanish locality, are lacking this feature and they are morphologically indistinguishable. The relationships among these three clades are unresolved to poorly-resolved based on all the mitochondrial datasets.

Based on the mitochondrial datasets, mean sequence divergence between $H$. ingens s.l. clades is always higher than the divergence within clades, with no overlap of values (Fig. 5), a criterion often used to delimit cryptic species (Hebert et al., 2003; Baird et al., 2011). Furthermore, the application of the $4 x$ rule to the "16S and Cyt-b" dataset and to the "COI" dataset in H. ingens s.l. (Table 4) confirmed these three clades as independently evolving lineages, i.e. species sensu De Queiroz (2007). The subgenus Occidodiaptomus thus appears to be composed of five taxa of species rank in contrast to the three taxa known for the group to date. Hemidiaptomus (O.) maroccanus and $H$. (O.) roubaui are confirmed as good species, whose identification can be soundly performed based on morphology alone. Conversely, three species are currently concealed within Hemidiaptomus (Occidodiaptomus) ingens, two of them being not distinguishable based on traditional morphology. 


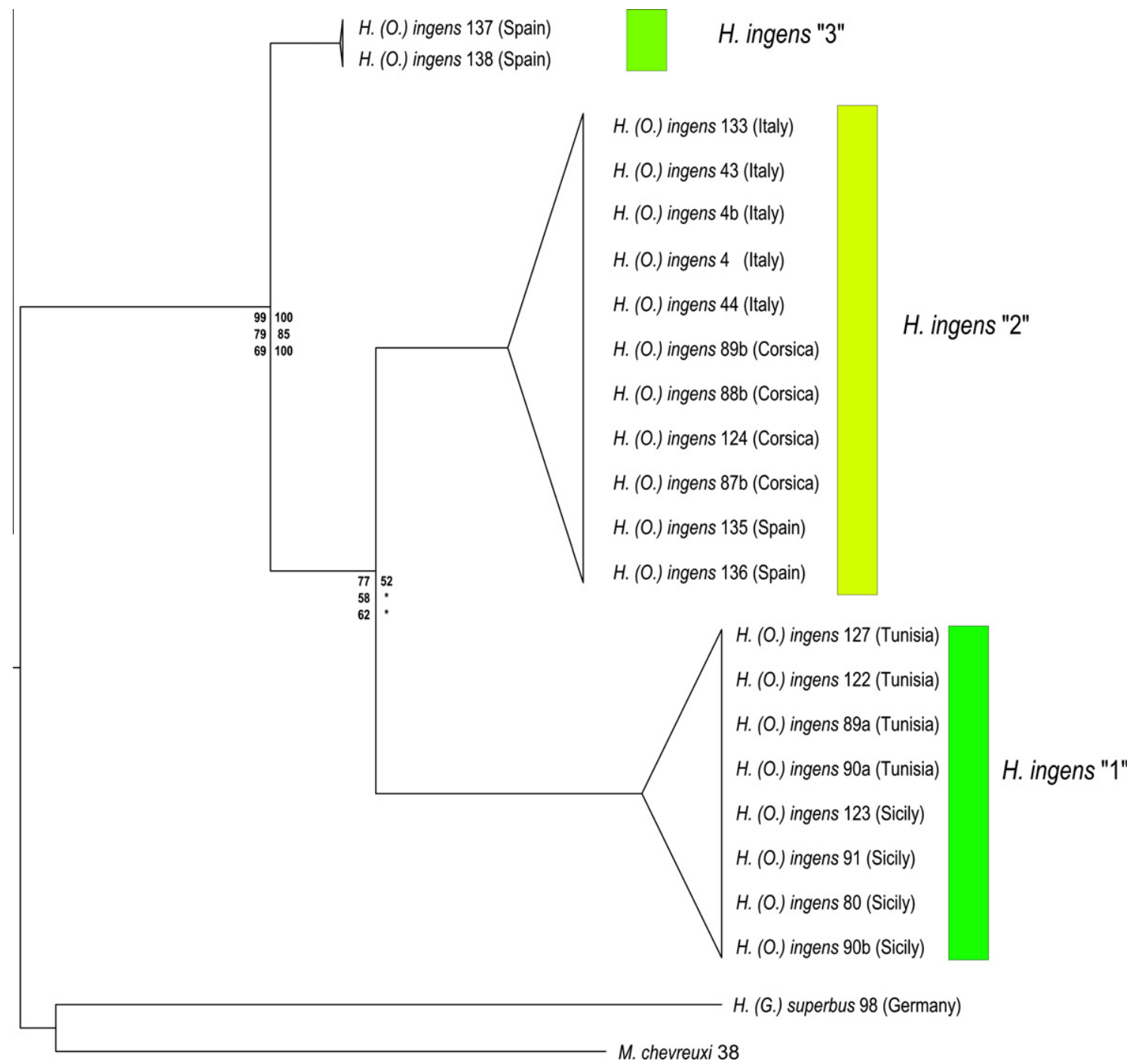

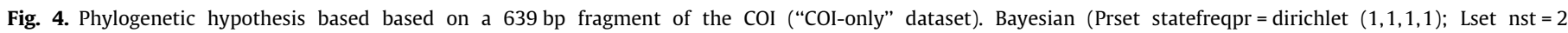

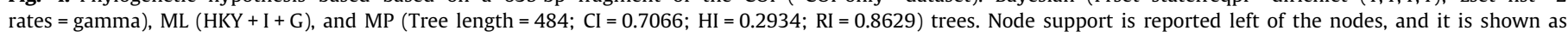

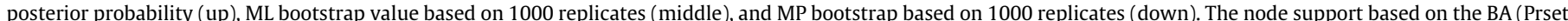

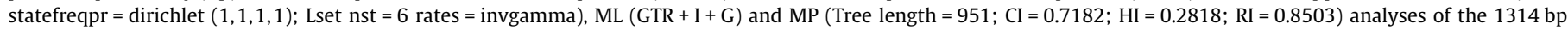
fragment of the "16S, Cyt-b and COI" dataset is reported right of the same nodes. "*” indicates node support lower than 50.

Within Hemidiaptomus ingens s.l., the Sicilian-Tunisian clade ("H. ingens 1") includes some populations collected a few kilometres apart from the type locality of Hemidiaptomus ingens (Gurney, 1909) and it is morphologically consistent with the original description of $H$. ingens given by Gurney (1909); it can thus be considered as "Hemidiaptomus ingens" s.str. However, it is currently impossible to give a formal name to the $H$. ingens " 2 " and " 3 " clades because the morphology of the subspecies " $H$. ingens inermis" (Kiefer, 1954) is consistent with both clades, and no molecular data are nowadays available for the topotypical $H$. ingens inermis population or for nearby Algerian populations.

\subsection{Phylogeography of the group}

The 'Monopolization Hypothesis' (De Meester et al., 2002) provides a theoretical basis to explain the extraordinarily high genetic distances observed between presumed conspecific and geographically close Occidodiaptomus populations in spite of the high potential for passive dispersal over wide geographical distances due to the production of resting eggs. The current distribution of the species and the pattern of molecular diversity of the subgenus
Occidodiaptomus (Fig. 6) allow to draw a working hypothesis on the phylogeography of the taxon. This scenario would locate the "ancestral area" of the subgenus, i.e. its ancestral range of distribution, on the Iberian plate. There are three facts which support this hypothesis: (i) the basal split between the clade of $H$. maroccanus and that of " $H$. roubaui $+H$. ingens s.l." is likely to be located in southern Iberia; (ii) the Iberian Peninsula hosts four of the five species currently known for the subgenus, and the single species missing there (i.e. H. ingens s.s.) occurs in northern Tunisia, that is on the former Numidian microplate of Iberian origin; and (iii) no species belonging to different Hemidiaptomus subgenera occurs south of the Pyrenees.

Based on the dating of the cladogenetic events based on the application of standard molecular clocks (Table 3 ), the subgenus Occidodiaptomus could have differentiated from Hemidiaptomus s.str. and Gigantodiaptomus due to the Pyrenean orogeny, which occurred about 35 mya (Meulenkamp and Sissingh, 2003) causing the onset of an insurmountable geographical barrier to the dispersal for these primarily lowland diaptomid species. The diversification within the subgenus is then to be ascribed to Oligocene and Miocene vicariance events (Table 3B and Fig. 7), likewise related to the palaeogeography of the area. An early split between the 
Table 3

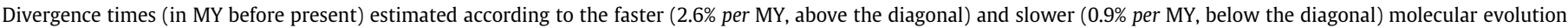

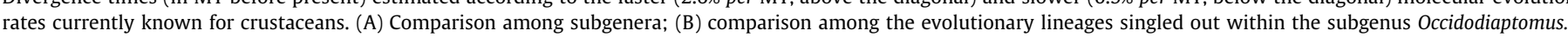

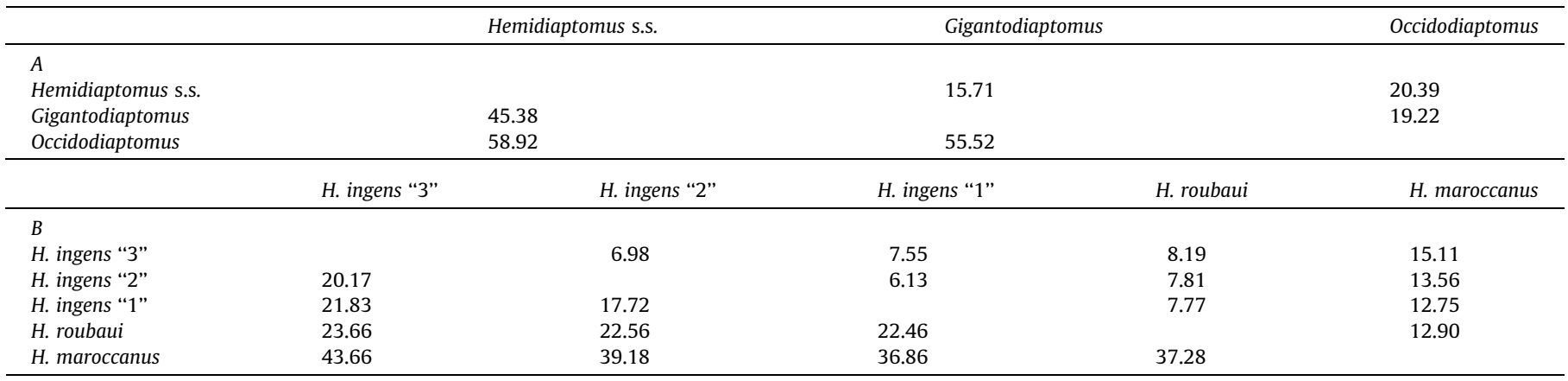

Table 4

Application of the " $4 \mathrm{x}$ rule" to Hemidiaptomus ingens s.l. mitochondrial lineages. (A) Four times the nucleotide polymorphism within each clade $(4 \Theta)$; (B) $\mathrm{K}$ among clades based on the ml-distance. Lower triangle: "16S and Cyt-b" dataset; upper triangle: "COI" dataset. See text for details.

\begin{tabular}{|c|c|c|c|c|}
\hline & \multicolumn{2}{|c|}{$16 S$ and Cyt-b dataset } & \multicolumn{2}{|c|}{ COI dataset } \\
\hline & p-Dist & ml-Dist & $p$-Dist & ml-Dist \\
\hline \multicolumn{5}{|l|}{$A$} \\
\hline 1. H. ingens " 1 " & 0.072187 & 0.085207 & 0.170092 & 0.204940 \\
\hline 2. H. ingens " 2 " & 0.125128 & 0.150050 & 0.164271 & 0.195284 \\
\hline \multirow[t]{2}{*}{ 3. H. ingens " 3 " } & 0.012519 & 0.012521 & 0.012519 & 0.012520 \\
\hline & \multicolumn{2}{|l|}{1} & 2 & 3 \\
\hline \multicolumn{5}{|l|}{$B$} \\
\hline 1. H. ingens " 1 " & \multirow{2}{*}{\multicolumn{2}{|c|}{0.202728}} & \multirow[t]{2}{*}{0.351258} & 0.319081 \\
\hline 2. H. ingens " 2 " & & & & 0.208427 \\
\hline 3. H. ingens " 3 " & \multicolumn{2}{|c|}{0.263195} & \multicolumn{2}{|c|}{0.245874} \\
\hline
\end{tabular}

ancestor of $H$. maroccanus and that of the lineage "H. roubaui $+H$. ingens s.l." took place in the late Oligocene, with the separation of the populations inhabiting the Baetic-Rif system (i.e. the core of the area currently inhabited by $H$. maroccanus) and those located north of this area. Such a pattern is known for other taxa (e.g.: Veith et al., 2004; Pfenninger et al., 2010) and is to be ascribed to an early separation of the Baetic-Rif area from the rest of the Iberian plate.

Hemidiaptomus maroccanus roughly remained in the area where the species originated through a vicariance event which differentiated it from the other species of the subgenus. Hemidiaptomus maroccanus is, in fact, the most divergent species of the group both based on morphology (Fig. 1) and on nuclear and mitochondrial data (Figs. 2 and 3). Furthermore, the only morphological character for which the ancestral state is known for diaptomid copepods, i.e. the antennulary chaetotaxy, is present in its ancestral form in $H$. maroccanus (i.e. two setae on the 16 th female antennular segment), while it is derived (i.e. a single seta on the 16 th female antennular segment) in all the other species of the group, further supporting the early split of $H$. maroccanus from the other Occidodiaptomus species.

The common ancestor of the subgroup " $H$. roubaui $+H$. ingens s.l.", occurring in the central and northern part of the Iberian plate, was then subject to cladogenetic events related to the fragmentation of the Iberian plate and the consequent isolation of the populations inhabiting the drifting microplates. This way, the ancestors of Hemidiaptomus ingens s.l. would differentiate in the drifting microplates, while the ancestor of $H$. roubaui likely remained in the Ibero-Provençal area, from where it expanded its distribution to southern Iberia and central and northern France during the Pleistocene. The heavily structured molecular tree for this last species mirrors the complex situation of the Iberian peninsula during the Plio-Pleistocene glacial events, when the existence of a complex network of refugia and a varied physiography enhanced the formation and survival of isolated local lineages, as already known for other animal groups (Gomez and Lunt, 2006).

This scenario is nowadays blurred by local extinctions and recent dispersal events, which have to be advocated to explain (i) the absence of well-differentiated Occidodiaptomus lineages in Sicily or Sardinia, (ii) the presence of $H$. roubaui in Sardinia, and in central and northern France, areas which could have been colonised only during the last 10,000 years, i.e. after the last glacial event, and (iii) the presence of Hemidiaptomus ingens " 2 " in Apulia, which is unexpected in the frame of the biogeography of a

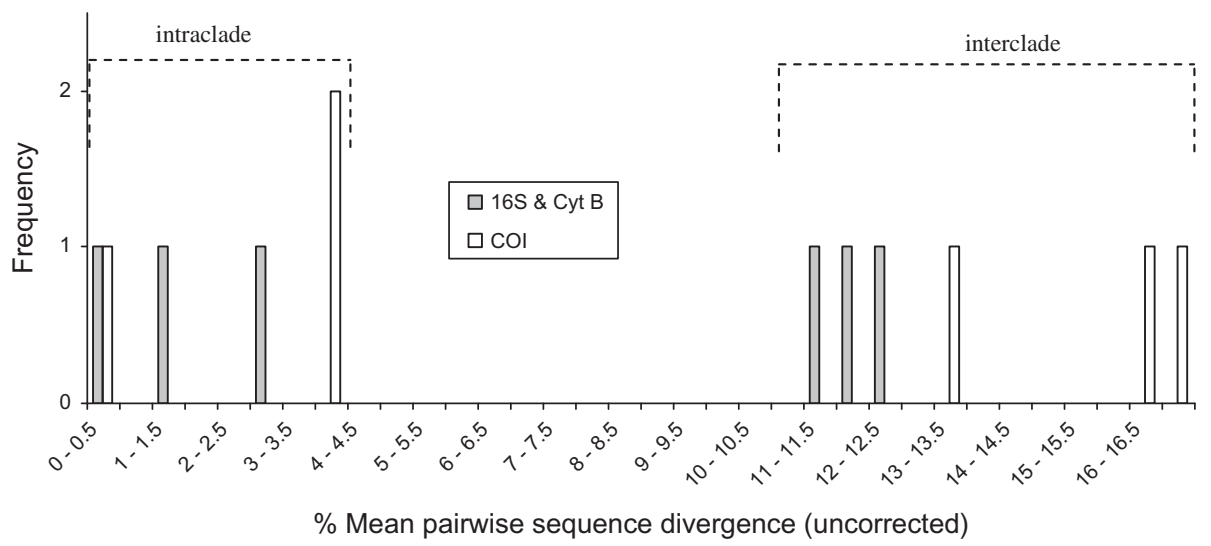

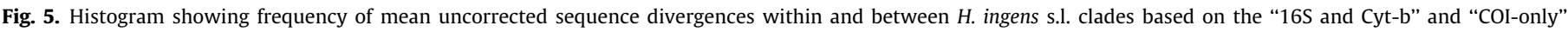
mitochondrial datasets. 


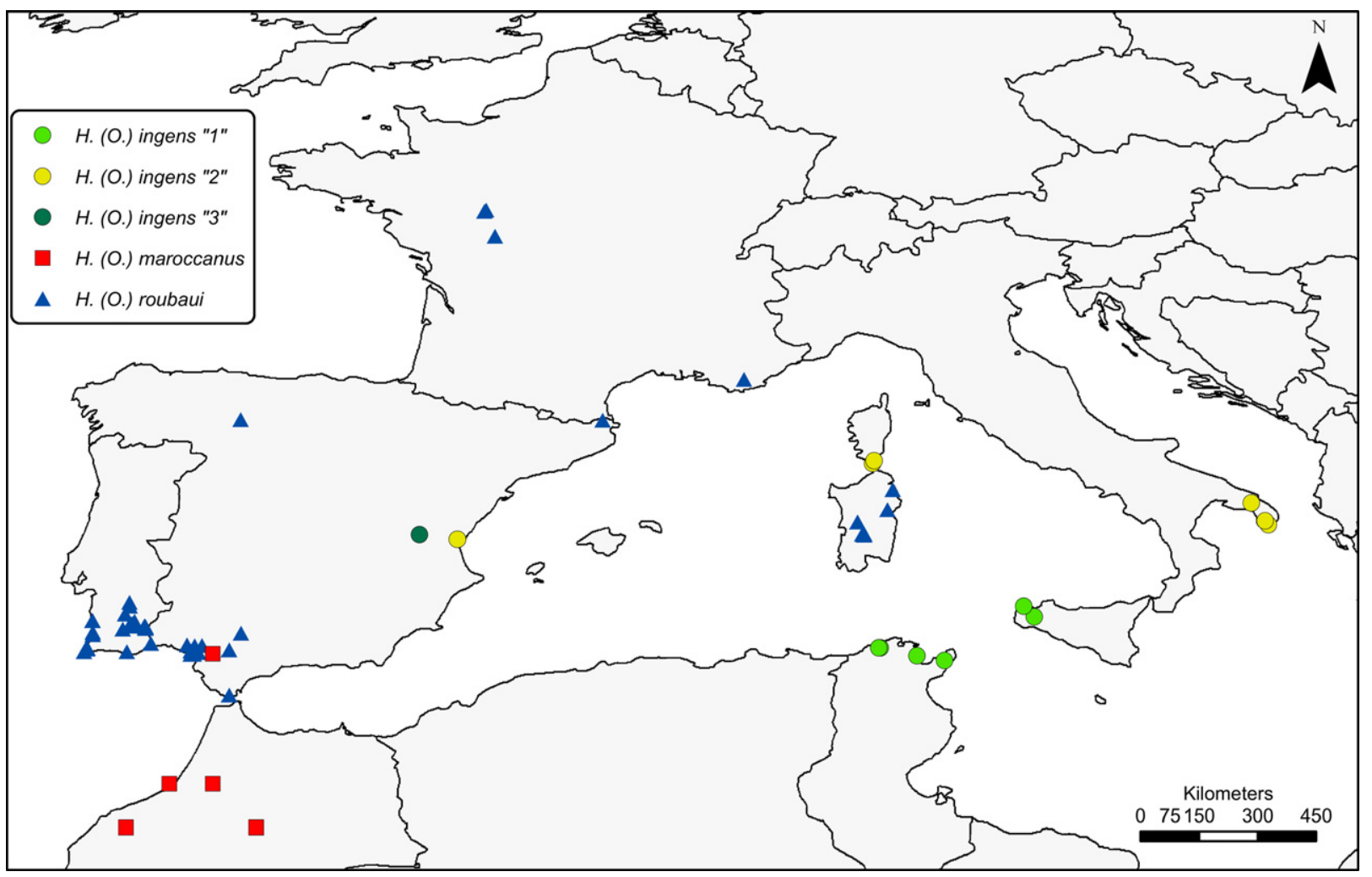

Fig. 6. Map of the Mediterranean area showing the sampled sites of the Occidodiaptomus species included in the analyses (see Table S1 for site details).

supposedly west-Mediterranean taxon. Furthermore, it is currently difficult to single out the distribution area for such a rare species as H. ingens "3", a taxon for which a single occurrence locality is currently known (Table 2 ).

The presence of Hemidiaptomus roubaui in Sardinia is particularly puzzling, as one would expect that a species belonging to $H$. ingens s.l. would occur there, possibly $H$. ingens " 2 ", which occurs also in southern Corsica and in north-eastern Spain. Conversely, in spite of an intense sampling effort, $\mathrm{H}$. roubaui is the only Hemidiaptomus species ever found in Sardinia, where it is rather common especially in the central and northern part of the island.

It is noteworthy that the high potential for passive dispersal of the Occidodiaptomus species seems to have not completely masked the original distribution pattern of the taxon as the dispersal events led to a successful colonisation only in those areas where no species of the group occurred, which is in good accordance with the Monopolization Hypothesis (De Meester et al., 2002), and in accordance with the existence of only extremely limited areas of sympatric co-occurrence of Occidodiaptomus species (cf. Table 1 and Fig. 6).

The current diversity and distribution of the species of the group is thus the result of a combination of ancient (OligoceneMiocene) vicariance speciations and more recent (Pleistocene to Holocene) dispersals and colonisation events. Similarly complex diversity patterns are known for other invertebrate species (e.g.: Montreuil, 2008; Fochetti et al., 2009; Pfenninger et al., 2010) and these are considered typical for palaeo-Tyrrhenian taxa.

\subsection{Some remarks on morphological and molecular evolutionary rates in copepods}

According to the fastest and the slowest crustacean mitochondrial evolutionary rates known to date, the species differentiation within the subgenus Occidodiaptomus is to be dated in temporal frames comprised between 6 and 15 or 17 and 43 mya, respectively (Table 3 ). Although already described for other invertebrate species (e.g. Gomez et al., 2002), such an ancient dating of the diversification of morphologically-similar to undistinguishable taxa belonging to a single subgenus is noteworthy and it is in sharp contrast with the hypothesis of Pleistocene diversification which is often advocated for explaining the current diversity patterns in the Holoarctic region (e.g. Hewitt, 2000; Thum and Harrison, 2009). In such cases, the use of taxon-specific, properly calibrated, evolutionary rates instead of the "standard" ones would be recommendable.

However, in copepods the estimate of taxon-specific evolutionary rates is hampered by the nearly complete absence of fossil records to be used as reference points for the calibration of molecular clocks. To date, only few fossil copepods are known (e.g. Palmer, 1960; Selden et al., 2010), and the only known freshwater calanoid fossil remains are spermatophores and egg sacks from late Quaternary sediments (Bennike, 1998). Moreover, a noteworthy morphological conservatism is known for those few microcrustaceans which left fossil evidences, and modern species which are morphologically similar or even indistinguishable might in fact be separated by an ancient history of independent evolution: modern morphological resemblance does not necessarily mirror recent cladogenetic events (Taylor et al., 1996; Rocha-Olivares et al., 2001; Suno-Uchi et al., 2008; Thum and Harrison, 2009).

Although it has been routinely applied to a number of freshwater crustacean taxa (e.g. Taylor et al., 1996; Braga et al., 1999; Korn et al., 2006; Thum and Harrison, 2009; Zofkova and Timms, 2009; Ketmaier et al., 2012), the application of standard molecular evolutionary rates to freshwater microcrustaceans is to be used with caution, as it might overestimate the divergence times of the studied taxa. This is possibly due to the very short life span, fast generation time and peculiar life history of microcrustacean species, which might give many more chances to mutations to take place, 

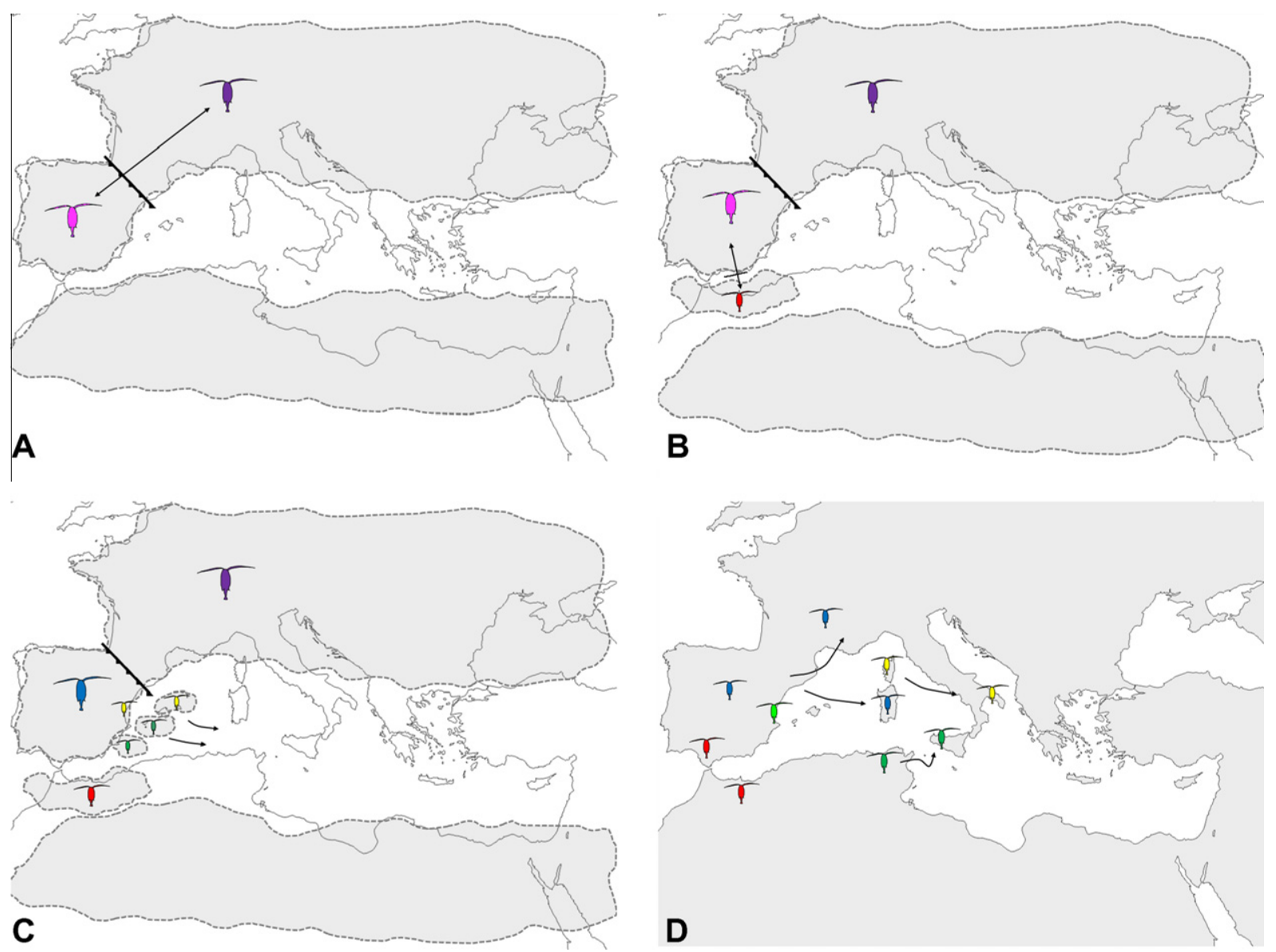

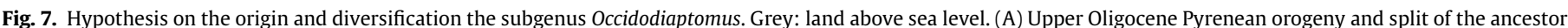

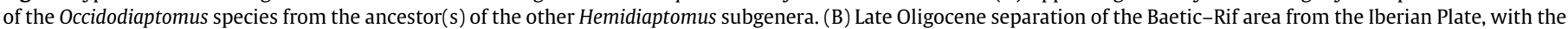

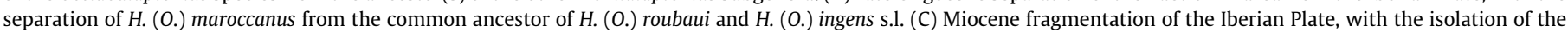

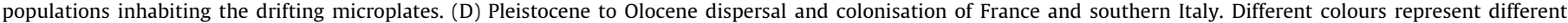

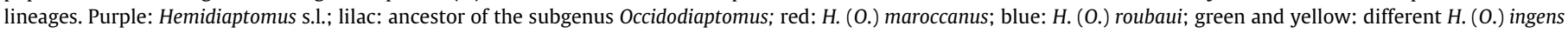
s.l. lineages. (For interpretation of the references to colour in this figure legend, the reader is referred to the web version of this article.)

when compared to observations in decapods or other malacostracan groups currently used for the calibration of "standard" molecular evolutionary rates (e.g. Knowlton and Weigt, 1998; Ketmaier et al., 2003). Furthermore, the possibility that mutagenic effects might act more incisively in shallow and ecologically-variable habitats has also to be considered: Zofkova and Timms (2009) suggested that the mutagenic effect of high UV exposure accelerates rates of molecular evolution in a fairy shrimp inhabiting shallow temporary ponds.

This study stresses once more the high frequency of "cryptic speciation" events in copepods (e.g. Lee, 2000; Grishanin et al., 2005; Thum and Derry, 2008; Makino and Tanabe, 2009; da Costa et al., 2011) and the apparent decoupling of morphological and molecular evolutionary rates in this group. A new, exciting challenge for the future copepod research is to find a way to deal with this decoupling: new models on the rates of molecular evolution in microcrustaceans are to be developed and tested for inland water copepods, taking in account the different natural history of different taxa.

\section{Data accessibility}

All the crustacean and DNA samples are stored in FM's crustacean collection at the "Dipartimento di Biologia ambientale e Biodiversità" of the University of Palermo.

Sequences are deposited in GenBank (Table S4; it will be realised upon acceptance of the ms).

\section{Acknowledgments}

We are grateful to M. Alonso, G. Alfonso, D. Boix, M.J. Caramujo, L. Demeter, D. Escoriza, H. Huét, D.M.P. Galassi, V. Korinek, M. Korn, M. Machado, N. Rabet, A. Ruhí, M. Sahuquillo, J. Sala, L. Samchyshyna, A. Sicilia, F. Stoch, and S. Turki for having provided diaptomid samples and/or having supported the sampling activities.

Part of this work was developed in the frame of the PhD of FM, both at the "Department of Environmental biology and Biodiversity" of the University of Palermo (Italy) and at the "Senckenberg Naturhistorische Sammlungen Dresden" (Germany).

FM was partially supported by a grant provided from the Italian “Accademia Nazionale dei Lincei” (Borsa di Studio in Planctologia "Lina Rizzo"), and from "Fondi di Ateneo" (ex 60\%).

\section{Appendix A. Supplementary material}

Supplementary data associated with this article can be found, in the online version, at http://dx.doi.org/10.1016/j.ympev.2012. 09.016 .

\section{References}

Alfonso, G., Belmonte, G., 2011. Calanoida (Crustacea Copepoda) from the inland waters of Apulia (south-eastern Italy). Journal of Limnology 70, 57-68. Alonso, M., 1998. Las lagunas de la Espaňa Peninsular. Limnetica 15, 1-176. 
Baird, H.P., Miller, K.J., Stark, J.S., 2011. Evidence of hidden biodiversity, ongoing speciation and diverse patterns of genetic structure in giant Antarctic amphipods. Molecular Ecology 20, 3439-3454

Barker, F.K., Lutzoni, F., 2002. The utility of the incongruence length difference test. Systematic Biology 51, 625-637.

Bennike, O., 1998. Fossil egg sacs of Diaptomus (Crustacea: Copepoda) in Late Quaternary lake sediments. Journal of Paleolimnology 19, 77-79.

Bilton, D.T., Freeland, J.R., Okamura, B., 2001. Dispersal in aquatic invertebrates. Annual Review of Ecology and Systematics 32, 159-181.

Birky Jr., C.W., Adams, J., Gemmel, M., Perry, J., 2010. Using population genetic theory and DNA sequences for species detection and identification in asexual organisms. PLoS ONE 5, e10609.

Blanco-Bercial, L., Bradford-Grieve, J., Bucklin, A., 2011. Molecular phylogeny of the Calanoida (Crustacea: Copepoda). Molecular Phylogenetics and Evolution 59, 103-113.

Bohonak, A.J., Jenkins, D.G., 2003. Ecological and evolutionary significance of dispersal by freshwater invertebrates. Ecology Letters 6, 783-796.

Boileau, M.G., 1991. A genetic determination of cryptic species (Copepoda: Calanoida) and their postglacial biogeography in North America. Zoological Journal of the Linnean Society 102, 375-396.

Borutzky, E.B., Stepanova, L.A., Koss, M.S., 1991. Opredelitel' Calanoida presnykh vod SSSR. Nauka, St. Petersburg.

Boxshall, G.A., Huys, R., 1998. The ontogeny and phylogeny of copepod antennules. Philosophical Transactions of the Royal Society of London B 353, 765-786.

Bradford-Grieve, J.M., Boxshall, G.A., Ahyong, S.T., Ohtsuka, S., 2010. Cladistic analysis of the calanoid Copepoda. Invertebrate Systematics 24, 291-321.

Braga, E., Zardoya, R., Meyer, A., Yen, J., 1999. Mitochondrial and nuclear rRNA based copepod phylogeny with emphasis on the Euchaetidae (Calanoida). Marine Biology 133, 79-90.

Bucklin, A., Frost, B.W., Bradford-Grieve, J., Allen, L.D., Copley, N.J., 2003. Molecular systematic and phylogenetic assessment of 34 calanoid copepod species of the Calanidae and Clausocalanidae. Marine Biology 142, 333-343.

Caramujo, M.J., Boavida, M.J., 2010. Biological diversity of copepods and cladocerans in Mediterranean temporary ponds under periods of contrasting rainfall. Journal of Limnology 69, 64-75.

Champeau, A., 1971. Originalité du peuplement de Copépodes dans les eaux temporaires de Basse-Provence et de Corse. Annales de l'Université de Provence. Science $45,55-80$

Costa, F.O., deWaard, J.R., Boutillier, J., Ratnasingham, S., Dooh, R.T., Hajibabaei, M., Hebert, P.D.N., 2007. Biological identifications through DNA barcodes: the case of the Crustacea. Canadian Journal of Fishery and Aquatic Sciences 64, 272295.

Cunningham, C.W., 1997. Can three incongruence tests predict when data should be combined? Molecular Biology and Evolution 14, 733-740.

da Costa, K.G., Vallinoto, M., da Costa, R.M., 2011. Molecular identification of a new cryptic species of Acartia tonsa (Copepoda, Acartiidae) from the Northern coast of Brazil, based on mitochondrial COI gene sequences. Journal of Coastal Research 64, 359-363.

De Meester, L., Gomez, A., Okamura, B., Schwenk, K., 2002. The monopolization hypothesis and the dispersal-gene flow paradox in aquatic organisms. Acta Oecologica 23, 121-135.

de Queiroz, K., 2007. Species concepts and species delimitation. Systematic Biology $56,879-886$.

Dooh, R.T., Adamowicz, J., Hebert, P.D.N., 2006. Comparative phylogeography of two North American 'glacial relict' crustaceans. Molecular Ecology 15, 4459-4475.

Dowton, M., Austin, A.D., 2002. Increased congruence does not necessarily indicated increased phylogenetic accuracy - the behaviour of the incongruence length difference test in mixed-model analyses. Systematic Biology 51, 19-31.

Dussart, B., Defaye, D., 2002. World Directory of Crustacea Copepoda of Inland Waters. I - Calaniformes. Backhuys Publishers, Leiden.

Einsle, U., 1993. Crustacea Copepoda. Calanoida und Cyclopoida. Süsswasserfauna Mitteleuropas, 8/4-1. Gustav Fischer Verlag, Jena.

Farris, J.S., Kallersjo, M., Kluge, A.G., Bult, C., 1995. Testing significance of incongruence. Cladistics 10, 315-319.

Figueroa, D.F., 2011. Phylogenetic analysis of Ridgewayia (Copepoda: Calanoida) from the Galapagos and of a new species from the Florida keys with a reevaluation of the phylogeny of Calanoida. Journal of Crustacean Biology 31, 153-165.

Fochetti, R., Sezzi, E., Tierno de Figuero, J.M., Modica, M.V., Oliverio, M., 2009. Molecular systematics and biogeography of the western Mediterranean stonefly genus Tyrrhenoleuctra (Insecta, Plecoptera). Journal of Zoological Systematics and Evolutionary Research 47, 328-336.

Gauthier, H., 1928. Recherches sur la faune des eaux continentales de l'Algérie et de la Tunisie. Thése Sciences, Minerva, Alger.

Gomez, A., Serra, M., Carvalho, G.R., Lunt, D.H., 2002. Speciation in ancient cryptic species complexes: evidence from the molecular phylogeny of Brachionus plicatilis (Rotifera). Evolution 56, 1431-1444.

Gomez, A., Lunt, D.H., 2006. Refugia within refugia: patterns of phylogeographic concordance in the Iberian Peninsula. In: Weiss, S., Ferrand, N. (Eds.), Phylogeography in Southern European Refugia: Evolutionary Perspectives on the Origins and Conservation of European Biodiversity. Kluwer Academic Publishers, Dordrecht.

Grishanin, A.K., Rasch, E.M., Dodson, S.I., Wyngaard, G.A., 2005. Variability in genetic architecture of the cryptic species complex of Acanthocyclops vernalis (Crustacea: Copepoda). I. Evidence from karyotypes, genome size, and ribosomal DNA sequences. Journal of Crustacean Biology 25, 375-383.
Guindon, S., Gascuel, O., 2003. A simple, fast, and accurate algorithm to estimate large phylogenies by maximum likelihood. Systematic Biology 52, 696-704.

Gurney, R., 1909. On the freshwater Crustacea of Algeria and Tunisia. Journal of the Royal Microscopical Society 443, 273-305.

Hall, T.A., 1999. BioEdit: a user-friendly biological sequence alignment editor and analysis program for Windows 95/98/NT. Nucleic Acids Symposium Series 41, 95-98.

Hebert, P.D.N., Ratnasingham, S., deWaard, J.R., 2003. Barcoding animal life: cytochrome c oxidase subunit 1 divergences among closely related species. Proceedings of the Royal Society of London B 270, 96-99.

Hewitt, G., 2000. The genetic legacy of the Quaternary ice ages. Nature 405, 907 913.

Huelsenbeck, J.E., Ronquist, F., 2001. MrBayes: Bayesian inference of phylogeny Biometrics 17, 754-755

Huys, R., Boxshall, G.A., 1991. Copepod Evolution. The Ray Society, London.

Ketmaier, V., Argano, R., Caccone, A., 2003. Phylogeography and molecular rates of subterranean aquatic Stenasellid isopods with a peri-Tyrrhenian distribution. Molecular Ecology 12, 547-555.

Ketmaier, V., Marrone, F. Alfonso, G, Paulus, K., Wiemann, A, Tiedemann, R., Mura, G., 2012. Mitochondrial DNA regionalism and historical demography in the extant populations of Chirocephalus kerkyrensis (Branchiopoda: Anostraca). PLoS ONE 7, e30082.

Kiefer, F., 1954. Freilebende Ruderfusskrebse (Crustacea Copepoda) aus Binnengewaessern Marokkos. Bulletin de la Société des Sciences naturelles et physiques du Maroc 34, 317-336.

Kiefer, F., 1957. Zur Kenntnis von Hemidiaptomus (Gigantodiaptomus) roubau (Richard, 1888) und H. (G.) ingens (Gurney, 1909) (Crust. Cop.). Zoologischer Anzeiger 159, 311-321.

Kiefer, F., 1968. Versuch einer revision der Gattung Eudiaptomus Kiefer (Copepoda Calanoida). Memorie dell'Istituto Italiano di Idrobiologia 24, 9-160.

Kiefer, F., 1973. Zur Kentniss der roubaui-Gruppe der Gattung Hemidiaptomus G.O Sars (Copepoda). Crustaceana 25, 281-291.

Kiefer, F., 1978. Das Zooplankton der Binnengewaesser. Freilebende Copepoda. Die Binnengewaesser, Band 26 Teil 2. E. Schweizerbart'sche Verlagbuchhandlung Stuttgart.

Kieneke, A., Martinez Arbizu, P.M., Fontaneto, D., 2012. Spatially structured populations with a low level of cryptic diversity in European marine Gastrotricha. Molecular Ecology 21, 1239-1254.

Knowlton, N., 1993. Sibling species in the sea. Annual Review of Ecology and Systematics 24, 189-216.

Knowlton, N., Weigt, L.A., 1998. New dates and new rates for divergence across the Isthmus of Panama. Proceedings of the Royal Society of London B 265, 2257 2263.

Korn, M., Marrone, F., Pérez-Bote, J.L., Machado, M., Cristo, M., Cancela da Fonseca, L., Hundsdoerfer, A., 2006. Sister species within the Triops cancriformis lineage (Crustacea, Notostraca). Zoologica Scripta 35, 301-322.

Lee, C.E., 2000. Global phylogeography of a cryptic copepod species complex and reproductive isolation between genetically proximate "populations". Evolution 54, 2014-2027.

Leibold, M.A., Economo, E.P., Peres-Neto, P., 2010. Metacommunity phylogenetics: separating the roles of environmental filters and historical biogeography. Ecology Letters 13, 1290-1299.

Makino, W., Tanabe, A.S., 2009. Extreme population genetic differentiation and secondary contact in the freshwater copepod Acanthodiaptomus pacificus in the Japanese Archipelago. Molecular Ecology 18, 3699-3713.

Marrone, F., Naselli-Flores, L., 2004. First record and morphological features of Hemidiaptomus (Occidodiaptomus) ingens (Gurney, 1909) (Copepoda Calanoida) in Italy. Journal of Limnology 63, 250-255.

Marrone, F., Lo Brutto, S., Arculeo, M., 2010. Molecular evidence for the presence of cryptic evolutionary lineages in the freshwater copepod genus Hemidiaptomus G.O. Sars, 1903 (Calanoida, Diaptomidae). Hydrobiologia 644, 115-125.

Marrone, F., Alfonso, G., Miserocchi, D., Lo Brutto, S., 2011. First record of Hemidiaptomus (Gigantodiaptomus) superbus (Schmeil, 1895) in Italy, with notes on distribution and conservation status (Copepoda, Calanoida, Diaptomidae). Journal of Limnology 70, 149-155.

Mayr, E., 1963. Animal Species and Evolution. Harvard University Press, Cambridge MA.

Meulenkamp, J.E., Sissingh, W., 2003. Tertiary palaeogeography and tectonostratigraphic evolution of the northern and southern Peri-Tethys platforms and the intermediate domains of the African-Eurasian convergent plate boundary zone. Palaeogeography, Palaeoclimatology, Palaeoecology 196, 209228.

Milligan, P.J., Stahl, E.A., Schizas, N.V., Turner, J.T., 2011. Phylogeography of the copepod Acartia hudsonica in estuaries of the northeastern United States. Hydrobiologia 666, 155-165.

Montreuil, O., 2008. Biogeographic hypothesis explaining the diversity of the genus Amphimallon Berthold, 1827, in the Mediterranean Basin (Coleoptera Scarabeidae, Melolonthinae). Palaeogeography, Palaeoclimatology, Palaeoecology 259, 436-452.

Mouelhi, S., Balvay, G., Kraiem, M.M., 2000. Branchiopodes (Ctenopodes et Anomopodes) et Copepodes des eaux continentales d'Afrique du Nord: inventare et biodiversite. Zoosystema 22, 731-748.

Nylander, J.A.A., 2004. MrModeltest v2. Program Distributed by the Author. Evolutionary Biology Centre, Uppsala University.

Palmer, A.R., 1960. Miocene copepods from the Mojave desert, California. Journal of Paleontology 34, 447-452. 
ARTICLE IN PRESS

F. Marrone et al./Molecular Phylogenetics and Evolution $x x x$ (2012) $x x x-x x x$

13

Petkovski, T.K., 1983. Calanoides - Calanoida (Crustacea Copepoda). Faune de Macedonie, 5. Musée Histoire Naturelle de Macedonie, Skopje.

Pfenninger, M., Véla, E., Jesse, R., Arantzazu Elejalde, M., Liberto, F., Magnin, F., Martinez-Ortì, A., 2010. Temporal speciation pattern in the western Mediterranean genus Tudorella P. Fischer, 1885 (Gastropoda, Pomatiidae) supports the Tyrrhenian vicariance hypothesis. Molecular Phylogenetics and Evolution 54, 427-436.

Ramdani, M., 1988. Les eaux stagnantes du Maroc: études biotypologique et biogéographique du zooplancton. Travaux de l'Institut scientifique, série zoologie, p. 43.

Ramirez, M.J., 2006. Further problems with the incongruence length difference test: "hypercongruence" effect and multiple comparisons. Cladistics 22, 289-295.

Reid, J.W., 1998. How "cosmopolitan" are the continental cyclopoid copepods? Comparison of the North American and Eurasian faunas, with description of Acanthocyclops parasensitivus sp.n. (Copepoda: Cyclopoida) from the USA. Zoologischer Anzeiger 236, 109-118.

Richard, J., 1888. Entomostracés nouveaux ou peu connus. Bulletin de la Société Zoologique de France 13, 43-48.

Rocha-Olivares, A., Fleeger, J.W., Foltz, D.W., 2001. Decoupling of molecular and morphological evolution in deep lineages of a meiobenthic harpacticoid copepod. Molecular Biology and Evolution 18, 1088-1102.

Ruffo, S., Stoch, F., 2005. Checklist e distribuzione della fauna italiana. 10.000 specie terrestri e delle acque interne. Memorie del Museo Civico di Storia Naturale di Verona, serie 2. Sezione Scienze della Vita 16, 1-307.

Sahuquillo, M., Miracle, M.R., 2010. Crustacean and rotifer seasonality in a Mediterranean temporary pond with high biodiversity (Lavajo de Abajo de Sinarcas, Eastern Spain). Limnetica 29, 75-92.

Selden, P.A., Huys, R., Stephenson, M.H., Heward, A.P., Taylor, P.N., 2010. Crustaceans from bitumen clast in Carboniferous glacial diamictite extend fossil record of copepods. Nature Communications 1, 50.

Stepanova, L.A., 2005. Composition of the genus Hemidiaptomus: identification of Gigantodiaptomus and Occidodiaptomus (Crustacea, Diaptomidae) as independent genera. Zoologicheskii Zhurnal 84, 754-760.
Suno-Uchi, N., Sasaki, F., Chiba, S., Kawata, M., 2008. Morphological stasis and phylogenetic relationships in Tadpole shrimps, Triops (Crustacea: Notostraca). Biological Journal of the Linnean Society 61, 439-457.

Swofford, D.L., 2003. PAUP*. Phylogenetic Analysis Using Parsimony (*and Other Methods). Version 4. Sinauer Associates, Sunderland, Massachusetts.

Taylor, D.J., Hebert, P.D.N., Colbourne, J.K., 1996. Phylogenetics and evolution of the Daphnia longispina group (Crustacea) based on 12S rDNA sequence and allozyme variation. Molecular Phylogenetics and Evolution 5, 495-510.

Tamura, K., Peterson, D., Peterson, N., Stecher, G., Nei, M., Kumar, S., 2011. MEGA5: molecular evolutionary genetics analysis using maximum likelihood evolutionary distance, and maximum parsimony methods. Molecular Biology and Evolution 28, 2731-2739.

Thum, R.A., 2004. Using 18S rDNA to resolve diaptomid copepod (Copepoda: Calanoida: Diaptomidae) phylogeny: an example with the North American genera. Hydrobiologia 519, 135-141.

Thum, R., Derry, A.M., 2008. Taxonomic implications for diaptomid copepods based on contrasting patterns of mitochondrial DNA sequences in four morphospecies. Hydrobiologia 614, 197-207.

Thum, R.A., Harrison, R.G., 2009. Deep genetic divergences among morphologically similar and parapatric Skistodiaptomus (Copepoda: Calanoida: Diaptomidae) challenge the hypothesis of Pleistocene speciation. Biological Journal of the Linnean Society 96, 150-165.

Veith, M., Mayer, C., Samraoui, B., Donaire Barroso, D., Bogaerts, S., 2004. From Europe to Africa and vice versa: evidence for multiple intercontinental dispersal in ribbed salamanders (Genus Pleurodeles). Journal of Biogeography 31, 159171.

Wyngaard, G.A., Holynska, M., Schute, J.A., 2010. Phylogeny of the freshwater copepod Mesocyclops (Crustacea: Cyclopidae) based on combined molecular and morphological data, with notes on biogeography. Molecular Phylogenetics and Evolution 55, 753-764.

Zofkova, M., Timms, B.V., 2009. A conflict of morphological and genetic patterns in the Australian anostracan Branchinella longirostris. Hydrobiologia 635, 67-80.

Please cite this article in press as: Marrone, F., et al. Overlooked cryptic endemism in copepods: Systematics and natural history of the calanoid subgenus

Occidodiaptomus Borutzky 1991 (Copepoda, Calanoida, Diaptomidae). Mol. Phylogenet. Evol. (2012), http://dx.doi.org/10.1016/j.ympev.2012.09.016 